(c) American Dairy Science Association, 2006.

\title{
Invited Review: Methods to Determine Body Fat Reserves in the Dairy Cow with Special Regard to Ultrasonographic Measurement of Backfat Thickness
}

\author{
U. J. Schröder ${ }^{1}$ and R. Staufenbiel \\ Klinik für Klauentiere, Freie Universität Berlin, D-14163 Berlin, Germany
}

\begin{abstract}
As the dairy cow uses body energy reserves in early lactation, body condition scoring has become an integral part of dairy herd management. Several methods based on visual and tactile evaluation have been developed. Problems caused by the subjectivity of these techniques have been reported. Alternative approaches to predict energy reserves or energy balance in dairy cattle include metabolic profiling and measurement of live weight, heart girth, or skinfold thickness. A less common method to assess fat reserves in body tissues is measuring backfat thickness (BFT) by using ultrasound. An ultrasound technique has been established to predict carcass quality in beef cattle. A new aspect is the application of ultrasound as a monitoring tool in dairy herd management where another location has to be evaluated. This technique has been validated by relating BFT to total body fat (TBF) content and carcass BFT. Backfat thickness also has been related to other methods of body condition scoring. Target values for the development of BFT throughout lactation are available. The relationship between BFT and TBF content is highly significant although biased by multiple factors. A change in BFT of $1 \mathrm{~mm}$ equates to approximately 5 $\mathrm{kg}$ of TBF content. Measuring BFT by ultrasound is of added value compared with other body condition scoring systems because it is objective and precise. Changes in body condition can be detected and evaluated properly.
\end{abstract}

Key words: body condition, ultrasonography, backfat thickness, dairy herd management

\section{INTRODUCTION}

One of the most important abilities of the dairy cow is the use of body energy reserves. This is indispensable to support high milk yield following parturition because the high-producing dairy cow undergoes a state of nega-

Received January 19, 2005.

Accepted September 28, 2005.

${ }^{1}$ Corresponding author: schroeder.ulf@vetmed.fu-berlin.de tive energy balance during early lactation. Adequate amounts of nutrients must be stored in body tissues during late lactation.

Because energy intake does not keep pace with continuously rising milk yield, energy deficit in early lactation increases, which leads to a competitive situation among milk yield, fertility, and health of the dairy cow because these traits are linked by energy requirement (Staufenbiel, 1992). As a consequence, relationships between high milk yield and reduced reproductive performance have been reported (Spalding et al., 1975; Faust et al., 1988). Conversely, high-yielding herds often achieve the fewest days open, indicating that this depression in fertility obviously can be offset by management decisions (Laben et al., 1982; Nebel and McGilliard, 1993).

As a part of dairy herd management, body condition scoring is an attempt to assess the magnitude of the energy deficit. Body condition scores are highly influenced by DIM and may be considered as an indicator of previous milk production and energy intake (Waltner et al., 1993). Therefore, it is suitable to assess the nutritional status of the dairy cow. The ideal body condition during each stage of lactation is that which optimizes milk production, minimizes reproductive and health disorders, and maximizes economic returns (Gearhart et al., 1990). Body condition primarily is a function of previous history and only one of many factors influencing milk yield, reproduction, and health status in progress of lactation. Although only a partial effecter, body condition is an important factor that is easily controlled. A precise assessment of body energy stores is needed to increase the efficiency of milk production. A method of measuring backfat thickness (BFT) by using ultrasound will be described and compared with other techniques of body condition scoring.

\section{ENERGY BALANCE AND BODY FAT RESERVES DURING LACTATION}

During early lactation, competition for limited sources of energy between rapidly increasing milk yield and limited DMI occurs in high-producing dairy cows. 
Maximum DMI lags behind peak milk yield (Coppock, 1985). This implies that, depending on milk yield, the dairy cow will drift into negative energy balance after calving. Every high-yielding dairy cow undergoes this stage of negative energy balance, but its duration and magnitude vary (Butler et al., 1981).

Changes in body lipid content also are influenced by genetics to a large extent. Genetically driven body lipid change is defined as that which occurs in cows kept in a non-constraining environment (Friggens et al., 2004). A model to predict the genetically driven changes in body lipid is available (Friggens et al., 2004).

Mobilization of body energy reserves during early lactation enables the cow to close the gap between oral energy intake and energy loss through milk production. Energetically, use of body tissues accounts for about $30 \%$ of milk production during the first month of lactation (Bauman and Currie, 1980; Bines and Hart, 1982). Duration of negative energy balance on average endures about 8 wk (Boisclair et al., 1986; Berghorn et al., 1988; Staples et al., 1990; Domecq et al., 1997) and varies from 5 (Stevenson and Britt, 1979) to $14 \mathrm{wk}$ (Gallo et al., 1996). This variability may be related to differences in energy intake and milk production as well as different approaches used to assess energy balance. Stevenson and Britt (1979) used BW, whereas Boisclair et al. (1986) showed that this yields a less precise estimate than BCS.

Negative energy balance leads to a homeorhetic response (Bauman and Currie, 1980) in which adipose tissue (by increased lipolysis), liver (by increased gluconeogenesis and glycolysis), muscle tissue (by protein mobilization), bone (by mineral mobilization), and gastrointestinal (GI) tract (by increasing capacity and activity) are involved (Lucy et al., 1991).

With mobilization of 50 to $60 \mathrm{~kg}$ of fat during early lactation, adipose tissue quantitatively represents the most important energy storage (Bauman and Currie, 1980; Smith and McNamara, 1990). Body protein and liver glycogen energetically play a minor role (Soderholm et al., 1986; Staufenbiel et al., 1991). Consequently, adipose tissue seems suitable to assess energy balance of the dairy cow because the amount of mobilized body fat approximates the energy demand that is lacking for milk production and maintenance (Waltner et al., 1993).

Depletion as well as replenishment of body fat reserves must not exceed certain limits. Some recommendations have been given for target BCS at defined stages of lactation (Braun et al., 1986; Parker, 1989; Heuwieser and Mansfeld, 1992). Overconditioning of dry dairy cows is a risk factor for an increased occurrence of metabolic, infectious, digestive, and reproductive disorders (Morrow, 1976; Morrow et al., 1979; Fronk et al., 1980; Garnsworthy and Topps, 1982; Gearhart et al., 1990). In addition, in Brown Swiss cows that tend to be fleshier and produce less milk than Holsteins, overconditioning during the periparturient period leads to reproductive disorders such as cystic ovaries, greater culling rates, and less milk yield (Mösenfechtel et al., 2000; Hasler et al., 2004).

Overconditioning usually starts during the last onethird of lactation, when milk production decreases and nutrient content in the diet is not adjusted adequately (Morrow et al., 1979). The dairy cow is not able to regulate energy intake autonomously when offered high grain diets (Boisclair et al., 1986). Other causes for overconditioned dry cows are extended lactations caused by delayed conception, prolonged dry periods resulting from earlier poor production, and overfeeding during the dry period (Morrow, 1976; Morrow et al., 1979).

Conversely, underconditioning can lead to reduced milk fat (Holter et al., 1990) and milk yield (Domecq et al., 1997) because of insufficient energy and protein reserves. Hence, for underconditioned high-yielding cows, it might be necessary to gain some condition in the dry period (Domecq et al., 1997). Poor BCS at parturition also reduces pregnancy rates at first $\mathrm{AI}$ (BCS $<2.5)$ and increases days open (BCS $\leq 3.5$ ) (López-Gatius et al., 2003). In beef cattle, the proportion of cows having normal estrous cycles before the beginning of the breeding season increased with greater BCS (Stevenson et al., 2003).

Change in BCS during the first month of lactation has a stronger influence on milk yield than condition at parturition. Thus, losing body condition has been associated with increased milk yield (Domecq et al., 1997). However, an extreme energy deficiency with excessive lipolysis has been related to health disorders such as fatty liver and ketosis, resulting in reduced milk yield (Grummer, 1993; Waltner et al., 1993; Rukkwamsuk et al., 1999, 2000). An increased loss of body condition in early lactation also is related to poor reproductive performance (Pryce et al., 2001). A decrease in $>1$ BCS unit during early lactation was associated with more days open (López-Gatius et al., 2003).

In most herds, use of high-energy feedstuffs and the feeding of TMR allows feeding groups to be formed in which cows are fed according to their milk yield and body condition. Body condition scoring becomes more important to separate fat from thin cows during late lactation to ensure an adequate replenishment of body tissue reserves in anticipation of the subsequent lactation. It is an essential tool to assess the magnitude of the physiological loss of body fat reserves in early lactation.

Similarly, assessment of body condition is of great importance in dairy heifers. Overconditioned heifers 
are at greater risk for dystocia and metabolic disorders in early lactation, whereas thin heifers may not grow adequately to calve at 24 mo or gain enough weight to support a normal first lactation (Morrow, 1976; Fronk et al., 1980; Hoffman et al., 1996).

\section{METHODS OF ESTIMATING BODY ENERGY RESERVES AND ENERGY BALANCE}

Respiration calorimetry is considered the gold standard approach to determine energetic metabolism, but it requires use of respiration chambers (Flatt et al., 1958; Moe et al., 1972), which makes this method unsuitable for use in the field.

Other, less accurate approaches estimate body water by dilution methods with deuterium oxide, tritiated water, urea, or antipyrine (AP). Estimated body water content can be used to predict body fat and protein and, thus, the amount of energy reserves (Panaretto and Till, 1963).

Another technique to assess changes in the amount of body fat is measurement of mean diameters of fat cells. In adult or nearly adult ruminants, an increase or decrease of adipose tissue mass is mainly due to changes in mean cell size, not cell number (Waltner et al., 1994). Measurement of fat cells is less invasive than dilution methods and less expensive to perform. It also removes the problem with variability in water flux because an attribute of the adipose organ is determined directly. Waltner et al. (1994) found mean cell diameters positively and linearly correlated to empty body fat (EBF) either as total amount of fat or as a percentage of BW.

All of these methods are unsuitable for field use, but can be helpful to validate the more practical instruments discussed later. For dairy herd management at least 6 methods are available to evaluate dynamics of body energy reserves.

\section{Live Weight}

Recording live weight (LW) reflects changes in protein as well as in fat, but many disadvantages are evident: percentages of protein, fat, and water in the body and, thus, the energy content per kilogram of LW, are highly variable (Reid and Robb, 1971; Staufenbiel et al., 1993). When body mass is depleted, a partial replacement by water in the tissues can be observed especially in early lactation, so that the amount of mobilized fat may be larger than the loss of BW (Moe et al., 1971). Conversely, energy can be stored by water displacement in mid and late lactation (Staufenbiel, 1985). Because LW includes GI content, it is influenced by DMI and time since last feeding. It is also biased by changing masses of organs and changing weight of the uterus and fetal-placental unit. In addition, frame size of the animal must be considered. Consequently, LW does not allow an independent or precise prediction of mobilization or storage of energy (Boisclair et al., 1986).

\section{Heart Girth Measurement}

Animal scales and restraint and handling systems necessary to determine LW are not always available on commercial dairy farms. Therefore, equations to estimate LW from other body measurements have been developed. For this purpose, heart girth, wither height, hip width, or body length can be used. Heinrichs et al. (1992) showed that each of these measurements is suitable to predict LW $\left(\mathrm{R}^{2}>0.95\right)$; heart girth has the largest correlation. Concerning energy balance, heart girth measurement has the same disadvantages as LW itself.

\section{Metabolic Profiling}

Another approach to estimate energy balance is analyzing the metabolic status by using blood and milk samples or test-day information. Various metabolic, hormonal, and milk traits have been shown to be related to energy balance. Concentrations of glucose, cholesterol, urea, insulin, insulin-like growth factor-1, triiodothyronine, and thyroxine in blood plasma and concentrations of lactose and urea in milk are correlated positively with energy balance. In contrast, concentrations of NEFA, creatinine, albumin, BHBA, growth hormone, and enzyme activities in blood and of acetone, fat, protein, and fat:lactose in milk are correlated negatively with energy balance (Kunz et al., 1985; Reist et al., 2002).

As indirect measures of negative energy balance (Herdt, 2000), postpartum NEFA and BHBA concentrations and prepartum NEFA concentrations are related to occurrence of displaced abomasum (Cameron et al., 1988; VanWinden et al., 2003, LeBlanc et al., 2005). Precision of estimating energy balance in individual cows is low (Herdt et al., 1981; Reist et al., 2002) and is generally influenced by diet composition (Herdt et al., 1981; Heuer et al., 2001). On a herd level, precision of prediction is also influenced by herd size (Heuer et al., 2000, 2001; Reist et al., 2002). To estimate energy balance with some precision, $\geq 100$ cows in seasonal calving herds should be available, and $\geq 400$ cows in nonseasonal calving herds should be available (Reist et al., 2002). A benefit of metabolic profiling is providing actual herd status. In contrast, body condition, and thus BFT, by virtue of the measurement, are always historic measures and might not reflect current dietary and 
herd status. Conversely, the advantage of body condition scoring lies within its immediate availability so that management decisions can be made on the farm.

\section{Body Condition Scoring}

Body condition scoring is a subjective estimate of the metabolizable energy reserves in the adipose tissue. It is based on evaluation of the outer appearance of the cow that interacts with its body fat reserves and, therefore, is directly influenced by energy balance. For beef cattle, a 9-point scale is commonly used (Wagner et al., 1988). A 5-point scale (Marlowe et al., 1962) and a 5to 15-point scale (Spelbring et al., 1977) have also been described.

Concerning dairy cows, 8- and 10-point scales are used in Australia and New Zealand (Roche et al., 2004). The Danish scoring system is based on a 9-point scale (Lassen et al., 2003). Prevailing scoring systems in the United States and Ireland use a 5-point scale in which a BCS of 1 indicates severe undercondition and a BCS of 5 indicates obesity. Relationships between different scoring systems have been described by Roche et al. (2004).

The BCS is determined by visual or tactile evaluation of the body at defined locations. Wildman et al. (1982), by appearance and palpation, examined the thoracic and lumbar regions of the vertebral column (chine, loin, and rump), spinous processes (loin), anterior coccygeal vertebrae (tailhead), tuber sacrale (hook bones), and tuber ischia (pin bones). Edmonson et al. (1989) revived these results and proposed a system under which cows were evaluated only visually at 8 body locations in the lumbar, thurl, and tailhead regions. They also used a 5point scale with 0.25 -unit increments. These 2 methods were reviewed and analyzed by Ferguson et al. (1994) to expand the usefulness of BCS. They assessed body condition at 7 body regions; visual and tactile cues were allowed. A simplified method has been published by University of Pennsylvania (Ferguson et al., 1994; Elanco, 1996). Body condition is scored step by step with only those body locations being examined that decisively contribute to the differences among scores.

Subjectivity, repeatability, and validity of BCS were investigated in several studies (Edmonson et al., 1989; Ferguson et al., 1994; Domecq et al., 1995). Edmonson et al. (1989) investigated repeatability and precision of the BCS chart they had developed. They found only small variability among the assessors. Practical experience of the scoring person did not significantly influence the result. In their study, BCS were not compared with any objective measurement of subcutaneous fat, and changes in body condition were not investigated.
In contrast, Ferguson et al. (1994) found less precision in the scoring results of untrained personnel. Scores evaluated by experienced persons were consistent with the mean BCS of all observers in 58 to $67 \%$ of the cases, whereas this was only $27 \%$ for an untrained investigator. Correlations among different observers ranged from 0.76 to 0.86 .

Individual consistency has also been investigated. The variation in BCS for experienced persons was 0.25 units for $40 \%$ of the observations. This result suggests that a change of 0.25 BCS units cannot be ascertained by one individual from 2 consecutive observations.

Statistical analysis showed that body condition can be separated into 0.25 -unit increments from a score of 2.5 to 4.0 . For scores $<2.5$ and $>4.0$, BCS can only be separated by 0.5 units (Ferguson et al., 1994).

Domecq et al. (1995) validated BCS with ultrasound measurements of subcutaneous fat in the lumbar, thurl, and tailhead areas. Body condition scores were significantly associated with ultrasound measurements, and coefficients of determination for the models ranged from 0.36 to 0.65 , depending on which ultrasound measurements were included in the calculation. The authors concluded that scoring body condition was as valid as ultrasound measurements to quantify the amount of subcutaneous fat in dairy cows. Concerning this latter statement, it should be noted that only 50 cows were examined, and no effort was made to determine whether changes in BCS were quantifiable.

Gearhart et al. (1990) reported an agreement of 94 to $97 \%$ of the scores for within and between individual variances. It should be noted that in the latter study, a deviation of one-third of a point on a 5-point scale was considered to be in agreement. Apparently, this approach is not sufficient to quantify changes in body condition.

\section{Skinfold Thickness}

Skinfold thickness is used to evaluate nutritional status in humans. This method has been used in dairy cattle (Bruckmaier et al., 1998). The skinfold value was defined as the mean of measurements obtained by a caliper at shoulder, dewlap, backside base of the udder, and base of the tail minus skinfold thickness in the neck region (almost no subcutaneous fat at this site). The researchers concluded that skinfold values behaved similarly to those of BCS and can be used in addition to BCS to assess the nutritional status of a dairy cow.

\section{Measurement of BFT}

Backfat is the layer of subcutaneous fat that is terminated by the skin and the fascia trunci profunda, which 


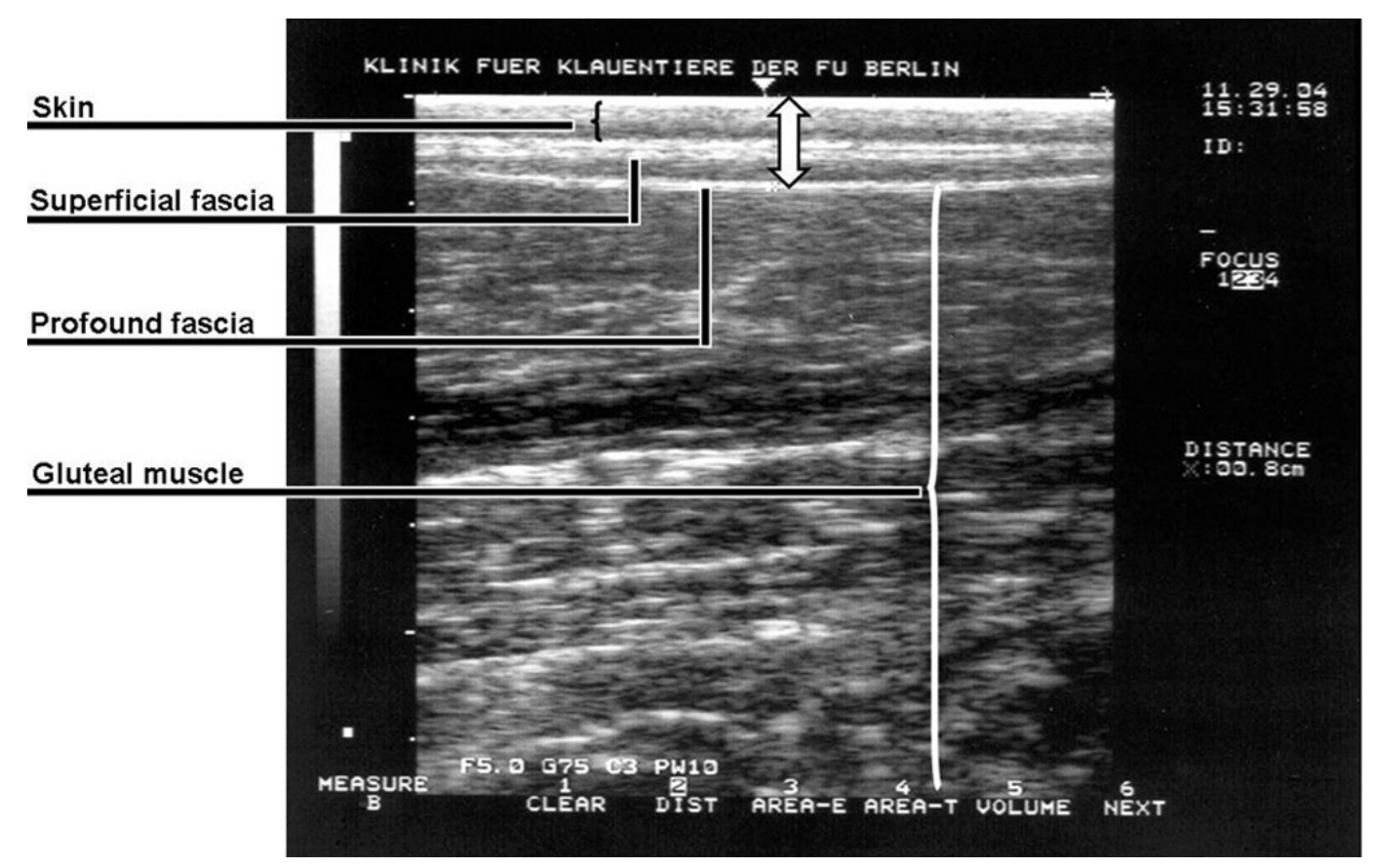

Figure 1. Ultrasound image illustrating backfat thickness (BFT) in a cow in poor condition (8 mm of BFT).

in this area is located above the gluteus medius and longissimus dorsi muscles.

Backfat thickness is most commonly evaluated by ultrasound. Previously used methods with skin-penetrating needles are now obsolete. These methods, however, were valuable for development and validation of the BFT technique. Two methods with a mechanical and electrical needle probe have been described (Staufenbiel, 1992).

Ultrasound examination is quick, non-invasive, and easy to learn. A portable B-mode ultrasound generator with a linear transducer and a frequency between 5.0 and 7.5 MHz is required. Skin contact with the transducer is made using 70 to $80 \%$ diluted alcohol. Hair coat needs not be clipped. Ultrasound equipment transfers electrical pulses into high-frequency sound waves by piezoelectric crystals. The image is generated by the sound waves being reflected from boundaries between different tissue densities (Houghton and Turlington, 1992), in this particular case, between adipose tissue, fascia, and muscle. The transducer is positioned vertically to an imaginary line between the hooks and pins at the sacral examination site. It must be held lightly and orthogonal to the interface of fat and muscle, because fat is compressed with pressure (Brethour, 1992). The cow should be in a normal, relaxed posture.

After freezing the image on the screen of the ultrasound machine, the layer of subcutaneous fat can be measured to the nearest $0.1 \mathrm{~cm}$. The fascia trunci pro- funda is clearly visible in almost every case (Figures 1 to 3 ). The skin thickness of 5 to $6 \mathrm{~mm}$ is always included in the ultrasound measurement, so that the actual subcutaneous fat thickness is less by that amount. A value of $6 \mathrm{~mm}$ of BFT consequently means an almost complete loss of body fat reserves.

Staufenbiel (1992) and Klawuhn (1992) examined the whole back region from the thoracic spine to the tail and found the sacral examination site to be most suitable for assessing BFT. The sacral region has the largest amount of adipose tissue in the back and high correlations $(r=0.90)$ exist between body fat content and BFT. Furthermore, the site is easy to locate, and BFT only changes slightly in a range of several centimeters.

The examination site is located in the sacral region between the caudal one-quarter and one-fifth connection line going from the dorsal part of the tuber ischia (pins) to the tuber coxae (hooks). This site corresponds to the area between the end of the crista sacralis and the end of the os sacrum (i.e., beginning of the first coccygeal vertebra; Figures 4 and 5). Tissue stratification at the measuring point becomes obvious in Figures 1 to 3 . In the sacral region, the skin diameter is about 5 to $6 \mathrm{~mm}$. The profound fascia is located directly on the gluteal muscle and appears as a white line in the ultrasound image. Backfat is positioned between the skin and the profound fascia. In most cows, the superficial fascia is present in the adipose tissue and appears as a thinner white line. It separates the backfat into 


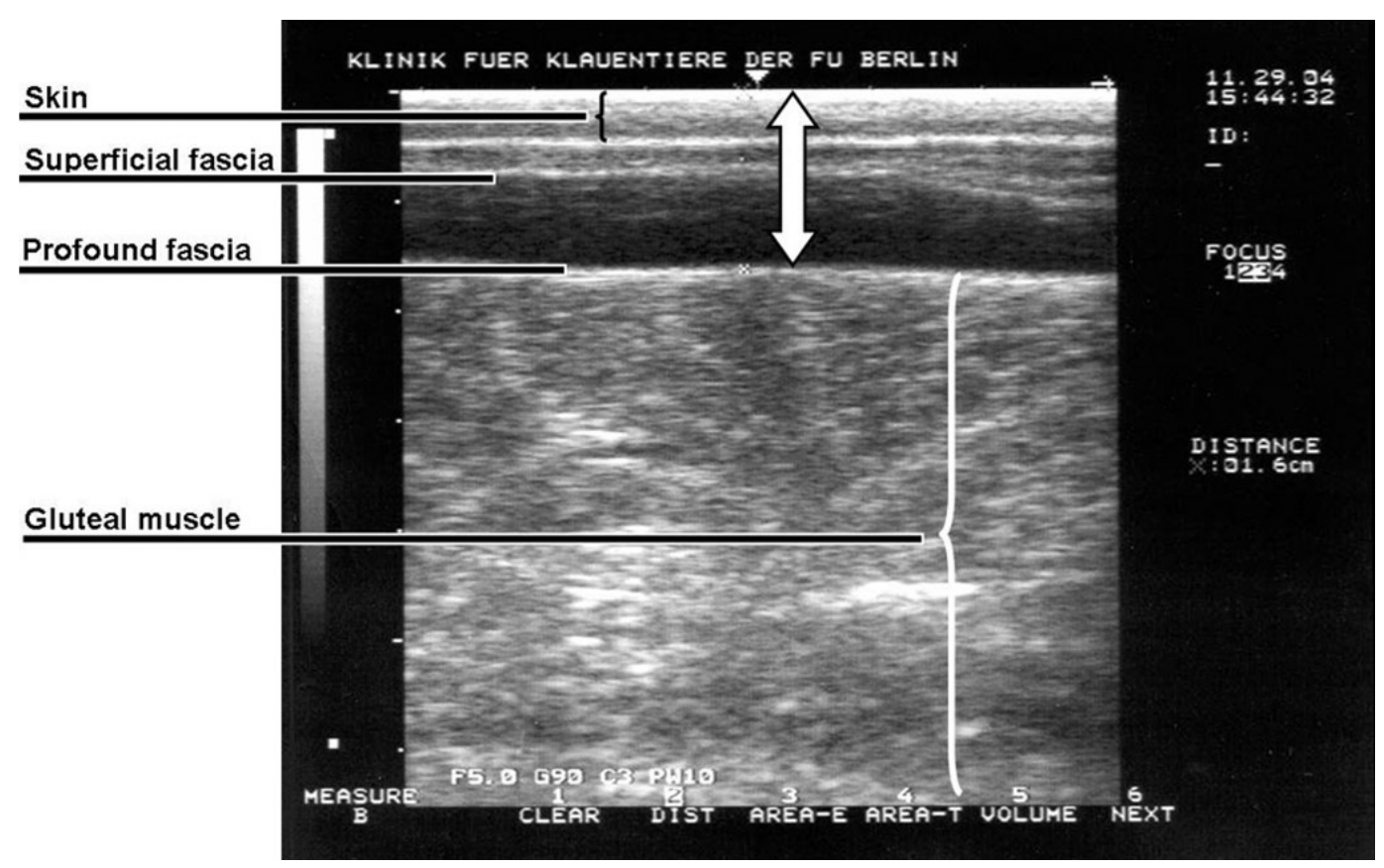

Figure 2. Ultrasound image illustrating backfat thickness (BFT) in a cow in moderate condition (16 mm of BFT).

subcutaneous fat and interfascial fat (Staufenbiel, 1992).

To quantify fat reserves in the cow, Domecq et al. (1995) examined the lumbar, thurl, and tailhead areas. The largest correlation $(r=0.86)$ was found between the right and left sides of the thurl. This area is located midway between the hooks and pins, 2 to $3 \mathrm{~cm}$ above the greater trochanter of the femur that coincides with the examination site described by Staufenbiel (1992). Neither combining lumbar and thurl area nor taking 2 sides into consideration improved the $\mathrm{R}^{2}$ in any model. Hence, Domecq et al. (1995) suggested that only one side and location of the cow needs to be evaluated.

BFT and Carcass Fat. Backfat thickness is one of the major quantitative traits that affects carcass quality in beef cattle and has been used to predict carcass retail yield components in live animals (Hamlin et al., 1995). Several studies have investigated the correlation between actual carcass BFT and that measured by ultrasound. Correlation coefficients ranged between 0.72 and 0.92 (Brethour, 1992; Perkins et al., 1992; Robinson et al., 1992; Greiner et al., 2003). Average absolute differences between ultrasonographically determined BFT and carcass BFT ranged from 1.6 (Brethour, 1992; Greiner et al., 2003) to $1.9 \mathrm{~mm}$ (Perkins et al., 1992). Discrepancies became larger when backfat was thicker (Brethour, 1992). Greiner et al. (2003) reported that leaner cattle were overestimated, and that fatter cattle were underestimated, by ultrasound.
Repeatability of ultrasound measurements also has been investigated. The correlation between consecutive measurements was 0.975 with an average absolute difference of $0.72 \mathrm{~mm}$ (Brethour, 1992). Robinson et al. (1992) reported an average standard deviation of 0.43 $\mathrm{mm}$ regarding within individual variances and approximately $1 \mathrm{~mm}$ for between individual variances.

Measurements for carcass evaluation usually are made at the 12th or 13th rib. These locations are not assessed when recording BCS. To make both methods comparable, the BFT examination site for dairy cows should be located in the thurl region (Domecq et al., 1995). That is the reason why, in contrast to beef cattle, the sacral examination site is used for the measurement of BFT in dairy herds (Staufenbiel, 1992).

BFT and Total Body Fat Content. To quantify the amount of body fat that is expressed by a certain BFT, it has been related to the total body fat (TBF) content. The TBF can be estimated by analysis of total body water (TBW). Both are inversely related with a high negative correlation of -0.97 (Panaretto and Till, 1963). Reid et al. (1955) found a correlation coefficient between fat and water contents of the whole empty body of -0.987 .

The principle of measuring TBW by dilution methods is based on the application of a test substance that dilutes evenly and only in TBW. When the distribution equilibrium is reached, the volume of TBW can be specified by calculation of the dilution ratio of the test sub- 


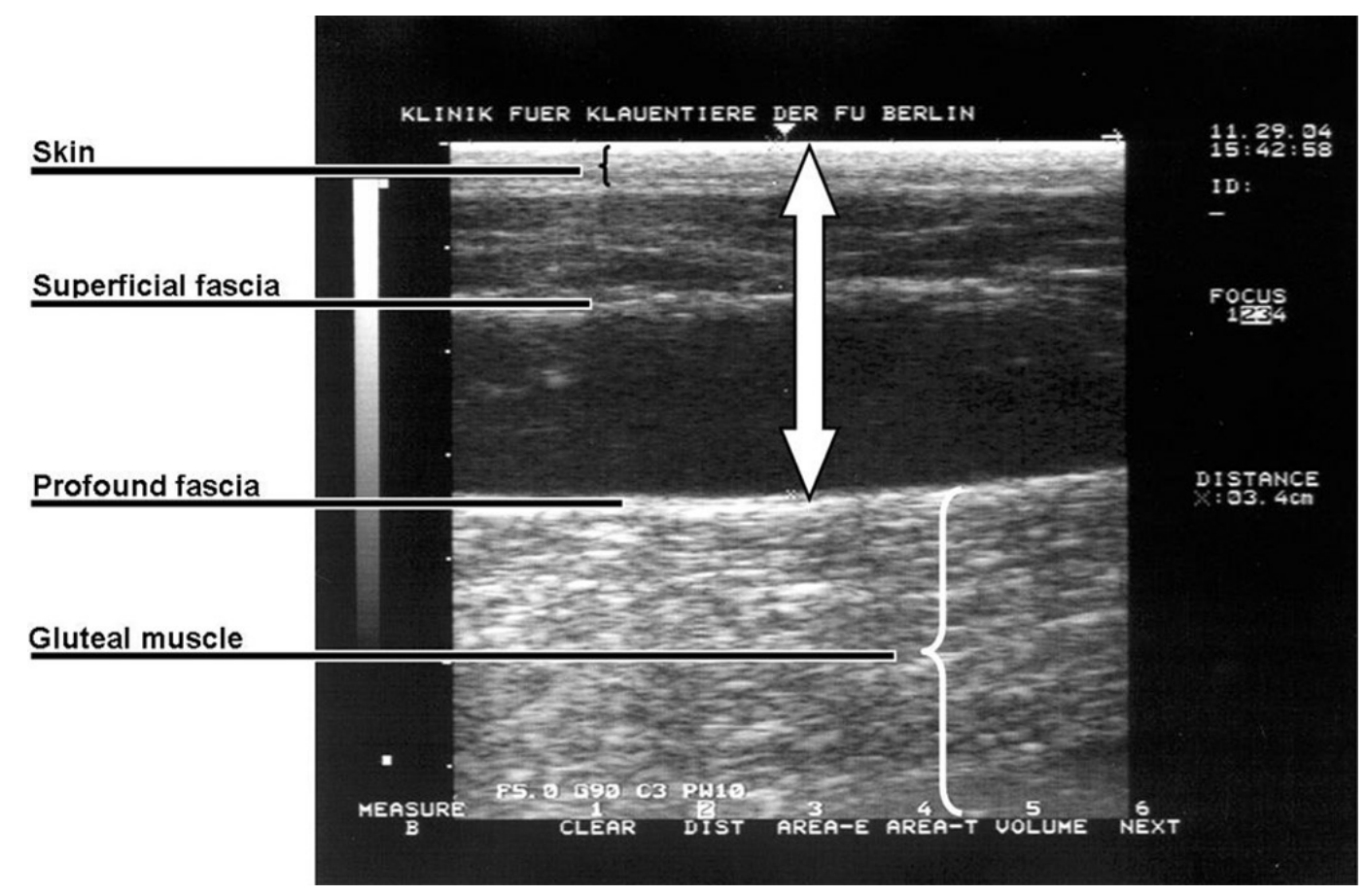

Figure 3. Ultrasound image illustrating backfat thickness (BFT) in a cow in fat condition (34 mm of BFT).

stance. Blood samples are collected at defined intervals to determine the concentration of the test substance. When equilibrium is reached, elimination is already in progress. The concentrations are recorded half-logarithmically and are then extrapolated to the time of administration (time zero). The aim is to calculate the theoretic concentration at time zero with uniform distribution and when none of the drug is being metabolized or eliminated. This forms the basis to calculate TBW.

Commonly used substances for the determination of TBW are tritiated water and deuterium oxide. Panaretto and Till (1963) found that tritiated water space overestimated TBW by a mean of $0.8 \%$ (both as percentages of LW) and thus yielded an accurate estimate. The correlation between tritiated water space and TBW expressed in liters was 0.982 and was 0.928 when expressed as a percentage of LW. Variable results are described in the literature due to the experimental procedure, especially time of fasting, administration and sampling technique, and species. Bird et al. (1982) reported that tritiated water space overestimated TBW by a mean of $12.3 \%$.

Considering the hazards of working with radioisotopes, especially with large animals, as well as the high costs for substances and equipment (Wiedemann, 1984), other dilution techniques with AP, urea, and ethanol have been developed (Soberman et al., 1949; Grüner, 1957; Bartle et al., 1987).
The urea dilution method has been described in the literature and yielded variable results depending on the technique used (Kock and Preston, 1979; Bartle et al., 1987; Cole, 1995). Andrew et al. (1995) found that urea space was not precise enough to determine differences in body components occurring during the lactation cycle. This imprecision may be due to the fact that urea is metabolizable. Thus, urea dilution does not seem to be suitable for estimating TBF (Wappler, 1997). It is also conceivable that urea dilution is less accurate in estimating body fat in Holstein breeds compared with beef breeds that have greater adipose reserves (Chelikani et al., 2003).

More reliable results can be obtained by using the AP dilution technique (Cole, 1995). Antipyrine evenly distributes in intra- and extracellular body water and rapidly reaches equilibrium (Soberman et al., 1949). It is slowly metabolized in cattle (Hix et al., 1959) and known to enter the gut water (Cole, 1995). Comparison of TBW calculated either by AP dilution or by tissue moisture analysis revealed a correlation coefficient of 0.939 (Wellington et al., 1956). Panaretto and Till (1963) determined a correlation of 0.988 between TBW and AP space expressed in liters and a correlation of 0.773 when expressed as a percentage of LW. Those researchers also considered that the AP space underestimated TBW by a mean of $4.4 \% \mathrm{LW}$. 


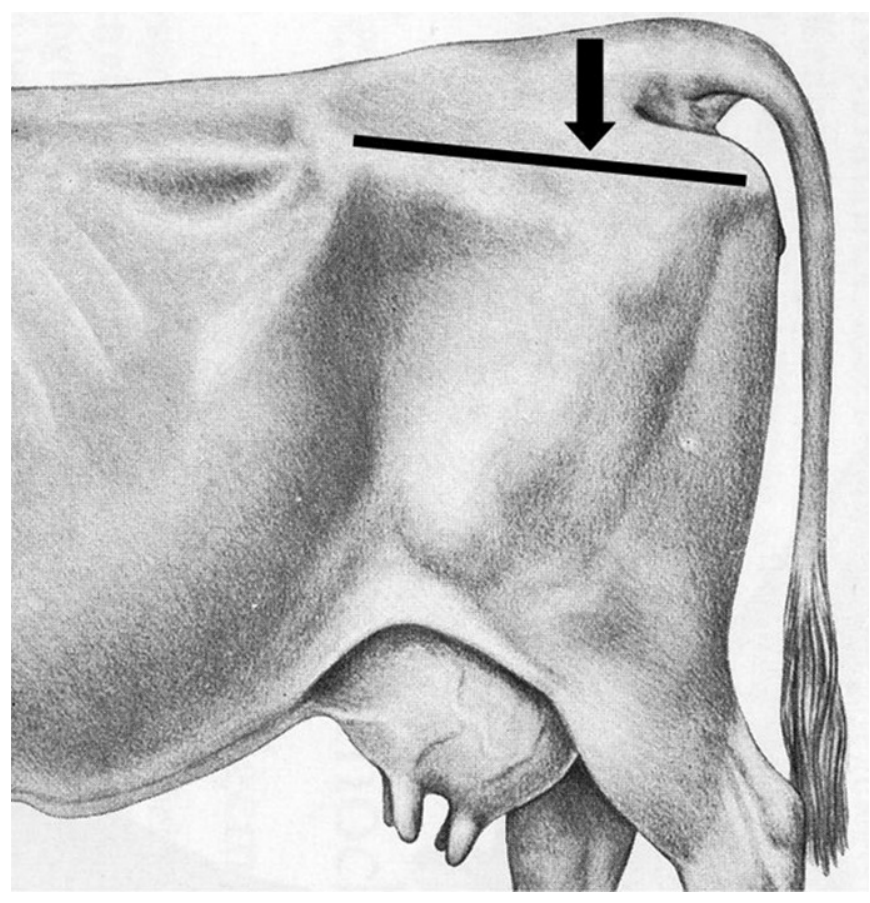

Figure 4. Location of the examination site (lateral view).

After calculating TBW, TBF can be estimated because the water content of the fat-free body mass is relatively constant in mature animals (Reid et al., 1955). Reid et al. (1955) calculated a water content of the fat-free whole empty body of $72.9 \pm 2 \%$ from all previous reports. Bird et al. (1982) found a TBW content of the fat-free whole body of $77.3 \%$ (75.9\% depending on the report). Based on these results, formulas were published to calculate absolute TBF and fat percentage of LW from TBW (Reid et al., 1955; Bird et al., 1982).

In the thoracic and lumbar spinal region, BFT was analyzed by Wiedemann (1989) using the electric needle probe method. The correlation between BFT and relative body fat $(\mathbf{R B F}=\mathrm{TBF} / \mathrm{LW})$ was 0.89 . One millimeter of BFT corresponded to a RBF of $0.94 \%$ of $\mathrm{LW}$.

The relationship between TBF and BFT measured with the mechanical needle probe method at the sacral examination site has been investigated in several studies (Klawuhn, 1992; Rieckhoff, 1992; Wappler, 1997). The information presented in Table 1 reveal consistent results, but a variation among and between reports is obvious. Correlation coefficients range from 0.28 to 0.94 . Regression coefficients that predict the change in TBF related to a $1-\mathrm{mm}$ change in BFT vary between 2.55 and 5.89. Several factors contribute to this variation. Distribution of fat reserves in the body may vary individually, and cows with smaller LW also have greater RBF despite similar BFT (Staufenbiel, 1992).

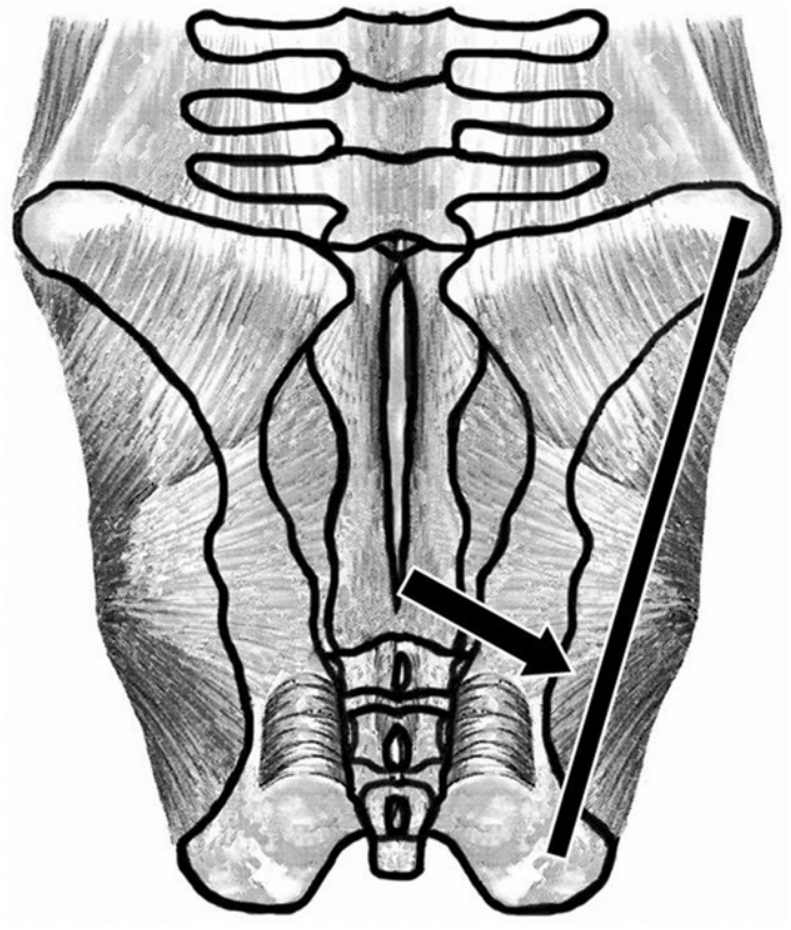

Figure 5. Location of the examination site (top view).

Because AP also distributes in the GI tract, drawbacks of this method arise from changes in body water flux rate and variations in the relative hydration of the digestive tract vs. other body tissues (Waltner et al., 1994). Variability in GI contents of ruminants can cause errors in the prediction of TBW (Andrew et al., 1995) because water pools in ruminants are highly dynamic (Hix et al., 1959; Cole, 1995). Andrew et al. (1995) noted that procedures are needed to differentiate GI water from empty body water (EBW).

An approach is the usage of $\mathrm{N}$-acetyl-4-aminoantipyrine (NAAP), which enters the GI tract to a much lesser extent than AP. Panaretto and Till (1963) showed, however, that both NAAP and AP spaces were biased. The NAAP space underestimated EBW by a mean of $6.3 \%$. Correlation coefficients between NAAP space and EBW were 0.895 when expressed in liters and 0.7 when expressed as a percentage of LW.

The systematic error associated with the calculation of TBW can be reduced by taking the cows off feed and water before injection of AP. A 24-h feed withdrawal (Wellington et al., 1956; Bird et al., 1982) or a 48-h feed withdrawal (Panaretto and Till, 1963) is used commonly to reduce variation in gut fill.

Another source of error is the water content of the fatfree body decreasing as cows age. Water concentration, however, is relatively constant after the cow has 
Table 1. Relationships between backfat thickness (BFT) and total body fat (TBF). Influence of lactation number, stage of lactation, and breed

\begin{tabular}{|c|c|c|c|c|c|c|}
\hline & No. & $\begin{array}{l}\text { Mean } \\
\text { BFT } \\
(\mathrm{mm})\end{array}$ & $\begin{array}{l}\text { Regression } \\
\text { coefficient } \\
\text { b }\end{array}$ & $\begin{array}{l}\text { Correlation } \\
\text { coefficient } \\
\mathrm{r}\end{array}$ & $P$ & Reference \\
\hline Dairy cows & 182 & 21 & 4.77 & 0.80 & $<0.001$ & Klawuhn (1992) \\
\hline Trial 1 & 73 & 25 & 5.85 & 0.82 & $<0.001$ & \\
\hline Trial 2 & 23 & 27 & 4.65 & 0.94 & $<0.001$ & \\
\hline Trial 3 & 86 & 15 & 4.73 & 0.68 & $<0.001$ & \\
\hline First lactation & 29 & 15 & 3.44 & 0.61 & $<0.001$ & \\
\hline Second lactation & 29 & 14 & 4.18 & 0.65 & $<0.001$ & \\
\hline Second or greater lactation & 28 & 17 & 5.38 & 0.73 & $<0.001$ & \\
\hline Early lactation & 31 & 16 & 4.31 & 0.69 & $<0.001$ & \\
\hline Midlactation & 27 & 13 & 3.76 & 0.55 & $<0.01$ & \\
\hline Late lactation & 29 & 16 & 5.83 & 0.73 & $<0.001$ & \\
\hline Beef bulls & 23 & 20 & 5.17 & 0.82 & $<0.001$ & \\
\hline Beef heifers & 204 & 13 & 5.27 & 0.87 & $<0.001$ & \\
\hline Dairy cows & 180 & 11.9 & 4.71 & 0.71 & $<0.001$ & Rieckhoff (1992) \\
\hline First lactation & 70 & 12.1 & 5.46 & 0.73 & $<0.001$ & \\
\hline Second lactation & 48 & 11.1 & 4.94 & 0.76 & $<0.001$ & \\
\hline Third lactation & 28 & 10.9 & 4.56 & 0.73 & $<0.001$ & \\
\hline Third or greater lactation & 12 & 15.0 & 4.30 & 0.78 & $<0.01$ & \\
\hline Early lactation & 42 & 10.3 & 2.55 & 0.28 & $<0.01$ & \\
\hline Midlactation & 77 & 11.5 & 4.59 & 0.69 & $<0.001$ & \\
\hline Late lactation & 61 & 13.2 & 5.02 & 0.76 & $<0.001$ & \\
\hline $\mathrm{HF}^{1}$ & 16 & 14.3 & 4.24 & 0.73 & $<0.001$ & \\
\hline $\mathrm{SMR}^{2}$ & 14 & 14.0 & 5.79 & 0.93 & $<0.001$ & \\
\hline Jersey & 16 & 17.3 & 4.37 & 0.90 & $<0.001$ & \\
\hline Dairy cows & 95 & 17.4 & 4.51 & 0.79 & $<0.05$ & Wappler (1997) \\
\hline Trial 1 & 6 & 33.2 & 5.60 & 0.94 & $<0.05$ & \\
\hline Trial 2 & 89 & 16.4 & 4.63 & 0.73 & $<0.05$ & \\
\hline First lactation & 19 & 14.9 & 3.53 & 0.59 & $<0.05$ & \\
\hline Second lactation & 17 & 15.9 & 5.27 & 0.65 & $<0.05$ & \\
\hline Third lactation & 32 & 17.5 & 4.39 & 0.81 & $<0.05$ & \\
\hline Third or greater lactation & 21 & 16.2 & 5.17 & 0.81 & $<0.05$ & \\
\hline Early lactation & 16 & 15.3 & 3.04 & 0.52 & $<0.05$ & \\
\hline Midlactation & 66 & 15.8 & 4.91 & 0.72 & $<0.05$ & \\
\hline Late lactation & 7 & 23.9 & 4.82 & 0.79 & $<0.05$ & \\
\hline $\mathrm{HF}^{1}$ & 25 & 15.4 & 5.89 & 0.78 & $<0.05$ & \\
\hline $\mathrm{SMR}^{2}$ & 64 & 16.7 & 4.46 & 0.76 & $<0.05$ & \\
\hline
\end{tabular}

reached "chemical maturity." The bovine is chemically immature until about $200 \mathrm{~d}$ of age and then enters a transitional stage and is chemically mature after about $500 \mathrm{~d}$ (Reid et al., 1955). Including age in the calculation only slightly improves the prediction of TBW and TBF (Bird et al., 1982). This implies that age is a factor of minor importance in adult dairy cows. Results in Table 1 , however, reveal some variation in body fat related to a 1-mm change in BFT caused by lactation number. It has been reported that primiparous cows contain less EBW than older cows (Martin and Ehle, 1986).

Variation also exists because of stage of lactation. Water to protein ratio in the empty body is influenced by lactation cycle, i.e., it is greatest for cows in early lactation and least for cows in late lactation (Andrew et al., 1995). Chaiyabutr et al. (1997) noted a significant reduction of TBW during lactation. Furthermore, GI fill increases from prepartum to 5 mo postpartum (Martin and Ehle, 1986), and lactating cows have a more rapid water turnover than nonlactating cows (Martin and Ehle, 1986; Chaiyabutr et al., 1997).

Body fluid compartments also are affected by pregnancy. In women, TBW increases during pregnancy and then decreases postpartum (Lukasi et al., 1994). In beef cows fed a limited diet [total feed intake equal to $70 \%$ NRC (1984)], EBW showed a steady decline from 3 mo of pregnancy until parturition, but tended to be constant when cows were fed greater amounts of feed [(total feed intake 110\% of NRC (1984); Shell et al. (1995)]. These data show that EBW is affected not only by pregnancy, but also by nutritional status.

In addition, there seems to be a breed-related influence. Water turnover rate, TBW space, and TBW as a percentage of BW were significantly greater in crossbred Holstein cattle (50\% Holstein-Friesian compared with $87.5 \%$ Holstein-Friesian cows; Chaiyabutr et al., 2000). In beef cattle, intramuscular fat is the largest depot followed by subcutaneous and internal fat, 
whereas dairy breeds deposit less subcutaneous fat and more internal fat than beef cattle (Dolezal et al., 1993).

Not only TBW and TBF, but also body condition scores, are influenced by breed. Holstein cows have lesser BCS, but greater BW than Jerseys (Washburn et al., 2002). This is not surprising, as there are strong genetic correlations for body condition and heart girth at different stages of lactation that are suitable to be used in breeding programs for dairy cattle (Gallo et al., 2001; Lassen et al., 2003).

In the field, another source of variation is the accuracy of ultrasound measurements. First of all, considerable variation exists between different investigators and ultrasonic instrumentation (Houghton and Turlington, 1992). Positioning of the transducer and its angle to the body surface as well as the thickness of the hair coat are further sources of error. The layer of subcutaneous fat is not uniform in a given location and might contribute to measurement error (Domecq et al., 1995). Backfat thickness was examined in 20 cows with 5 consecutive measurements on each side of the cow (Schröder, 2000). Absolute BFT ranged from $7.8 \pm 0.4$ to $39.8 \pm 0.4 \mathrm{~mm}$. When assessing error of the measurement, asymmetrical distribution between the 2 body sides is evident in some cows. When consistently measuring from the same side, the coefficient of variation was 0.03 (right side) and 0.04 (left side); the maximum absolute deviation was $1 \mathrm{~mm}$, which complies with the metering precision of the ultrasound machine. Some larger deviations occurred in single cows between the left and right sides. Disregarding body side, the coefficient of variation was 0.05 with a maximum deviation of $2.3 \mathrm{~mm}$. Even this error must be considered small; therefore, we can deduce, in agreement with Domecq et al. (1995), that only one side needs to be evaluated.

Overall accuracy for consecutive ultrasound measurements ranged between 1 and $2 \mathrm{~mm}$ (Brethour, 1992; Perkins et al., 1992; Robinson et al., 1992; Greiner et al., 2003). Discrepancies became larger with increasing BFT. This larger error can be explained by variations in posture, greater subjectivity in selecting a measurement site, and fluctuations with respiration on fatter cattle (Brethour, 1992). The researchers concluded that ultrasound is sufficiently sensitive over time to detect subtle changes in BFT.

BFT and Body Condition Scoring. Body condition scores have been related to BW with variable results. Using a 9-point scale, one BCS unit was associated with a change in BW of $33 \mathrm{~kg}$ [Angus and Angus crossbred; Lalman et al. (1997)] to $51 \mathrm{~kg}$ [Angus, Hereford, Red Poll, Braunvieh, Gelbvieh, Simmental, Pinzgauer, Charolais, and Limousin; Ferrell and Jenkins (1996)]. On a 5-point scale, BW change of one BCS unit was 56 $\mathrm{kg}$ for Holsteins (Otto et al., 1991), $68 \mathrm{~kg}$ for Angus
Table 2. Assessment of body condition by description, BCS, backfat thickness (BFT), and total body fat content $(\mathrm{TBF})^{1}$

\begin{tabular}{llcc}
\hline Description & BCS & BFT $(\mathrm{mm})$ & TBF $(\mathrm{kg})$ \\
\hline Emaciated & 1.0 & $<5$ & $<50$ \\
Very poor & 1.5 & 5 & 50 \\
Poor & 2.0 & 10 & 76 \\
Moderate & 2.5 & 15 & 98 \\
Good & 3.0 & 20 & 122 \\
Very good & 3.5 & 25 & 146 \\
Fat & 4.0 & 30 & 170 \\
Adipose & 4.5 & 35 & 194 \\
Obese & 5.0 & $>35$ & $>194$ \\
\hline
\end{tabular}

${ }^{1}$ Staufenbiel (1997).

(Buskirk et al., 1992), and $85 \mathrm{~kg}$ for Holsteins (Fox et al., 1999). Houghton et al. (1990) reported that empty BW increased 56.3 to $99.2 \mathrm{~kg}$ per BCS unit (5-point scale; Charolais $\times$ Angus) depending on absolute BCS. Tennant et al. (2002) suggested that weight adjustments for changing BCS are not proportional across the range of possible condition scores. Regarding all of these studies, the general disadvantages of LW measurement must be taken into consideration.

In Holsteins, BCS has been related to EBF with greater consistency. One BCS unit equated to 42 (Komaragiri and Erdman, 1997), 46 (Waltner et al., 1994), or $55 \mathrm{~kg}$ (Komaragiri et al., 1998) of EBF. Most of the loss in LW is caused by mobilization of body fat because body energy reserves are predominantly stored in the adipose tissue (Bauman and Currie, 1980).

It can be summarized that one BCS unit correlates to about $50 \mathrm{~kg}$ of EBF. With these results, the BCS system can be related to BFT measurement. Because a 1-mm change in BFT is associated with about $5 \mathrm{~kg}$ of body fat (Klawuhn and Staufenbiel, 1997; Staufenbiel, 1997), one BCS unit equates to about $10 \mathrm{~mm}$ of BFT. Body condition scores have been related to BFT with correlation coefficients ranging between 0.91 and 0.95 (Wittek and Fürll, 2002). A comparison of BCS, BFT, and TBF is presented in Table 2 (Staufenbiel, 1997).

Especially in free stalls, the BCS system benefits from being a simple method with high feasibility. Using BCS is a useful management tool to assess the nutritional status of dairy cows (Edmonson et al., 1989; Hady et al., 1994a,b). The precision achievable by BCS was discussed earlier. Investigating the accuracy of subjective scoring systems, Löschner and Staufenbiel (1996) reported that overestimation occurs particularly in early lactation, in young cows, and in lean cows with BFT values $<15 \mathrm{~mm}$. In contrast, body condition is more likely to be underestimated in the dry period, in older cows, and in fat cows with $>30 \mathrm{~mm}$ of BFT. Because of the different amounts of muscle mass, a risk exists for underestimating Holstein cows in comparison with 
dual-purpose or beef cattle (Staufenbiel, 1997). In Brown Swiss cows, for example, Mösenfechtel et al. (2000) recommended the use of BFT measured by ultrasound rather than BCS.

\section{CONCLUSIONS}

To evaluate energy balance precisely, laboratory conditions are necessary. For the estimation of energy balance in the field, several methods are available, and each of them shows advantages and disadvantages. Metabolic profiling yields an actual status of the herd, but misses an immediate availability. Body-based methods, conversely, provide instant information, but are always historic. Of these, measurements of LW and heart girth are not sufficiently precise to predict energy balance. Measurement of skinfold thickness has not been well validated and is not commonly used. The BFT measurement has been validated by carcass backfat and TBF measurements. It has become obvious that the relationship between BFT and TBF is biased by several different factors. Nevertheless, correlation coefficients between these 2 traits, based on biological features, are relatively high. Multiple sources of error in determining the absolute amount of body fat that is associated with changes in BFT are expressed in variable values of correlation and regression coefficients (Table 1). Klawuhn and Staufenbiel (1997) concluded that TBF changes by approximately $5 \mathrm{~kg}$ with each millimeter of BFT difference. Considerable variation exists, however, due to lactation number, stage of lactation, feed intake, and nutrition management.

Specific quantitative equations that describe the variation of body condition during lactation and relate it to production variables are needed as guidelines to make management decisions (Waltner et al., 1993; Gallo et al., 1996). A reference curve for the development of body condition throughout lactation has been reported for crossbred German Black Pied $\times$ Holstein cows (Schröder and Staufenbiel, 2003). It was based on 36,019 measurements evaluated in a cross-sectional study (Figure 6). A standard curve for the daily change of BFT has also been calculated (Schröder and Staufenbiel, 2003) for which 5,525 cows were measured twice at 4-wk intervals (Figure 7).

Based on this information, the BFT measurement has become a common tool in German dairy herd management. Cross-sectional studies must show whether these reference curves are applicable in the United States, considering a breed-related difference between Holstein and crossbred dairy cows.

A second body-based method suitable to evaluate the nutritional status of a dairy herd or a single cow is the BCS system. It is well validated and easy to use,

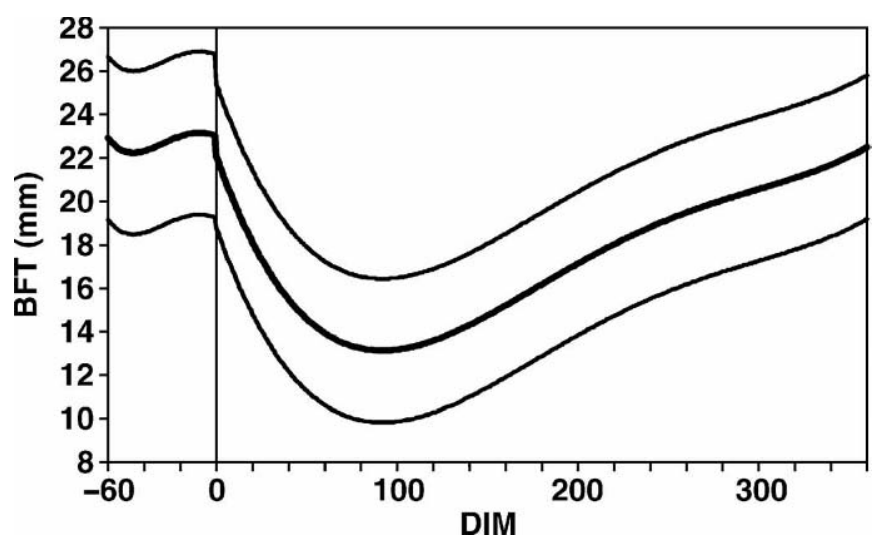

Figure 6. Reference curve for backfat thickness (BFT) throughout lactation for crossbred German Black Pied cows (BFT $\pm 0.5 \mathrm{SE}$ ) computed by polynomial regression. Descriptive statistics: $\mathrm{n}=33,412$, fat-corrected milk yield $=7,945 \pm 1,729 \mathrm{~kg}$, lactation number $=2.5$ \pm 1.6 , and days open $=124.4 \pm 70$. Regression equation for lactation: $\mathrm{BFT}=22.069-0.236 \mathrm{DIM}+2.01 \times 10^{-3} \mathrm{DIM}^{2}-6.0 \times 10^{-6} \mathrm{DIM}^{3}+$ $6.32 \times 10^{-9} \operatorname{DIM}^{4}\left(\mathrm{n}=29,106 ; \mathrm{SE}=6.6 ; \mathrm{R}^{2}=0.146\right)$ and for dry period: $\mathrm{BFT}=22.987-3.2 \times 10^{-2} \mathrm{DIM}-1.7 \times 10^{-3} \mathrm{DIM}^{2}+3.32 \times 10^{-7} \mathrm{DIM}^{4}$ $\left[\mathrm{n}=4,306 ; \mathrm{SE}=7.49 ; \mathrm{R}^{2}=0.002 ;\right.$ Schröder and Staufenbiel (2003)].

especially under free-stall conditions. In comparison with BCS, added value of measuring BFT lies within its objectivity and precision, especially when evaluating changes in body condition. It is quantitatively differentiable and provides comparability between different persons, breeds, and herds. Because of the1-mm metering precision of the ultrasound technique, even slight changes in body condition that may not be appreciable

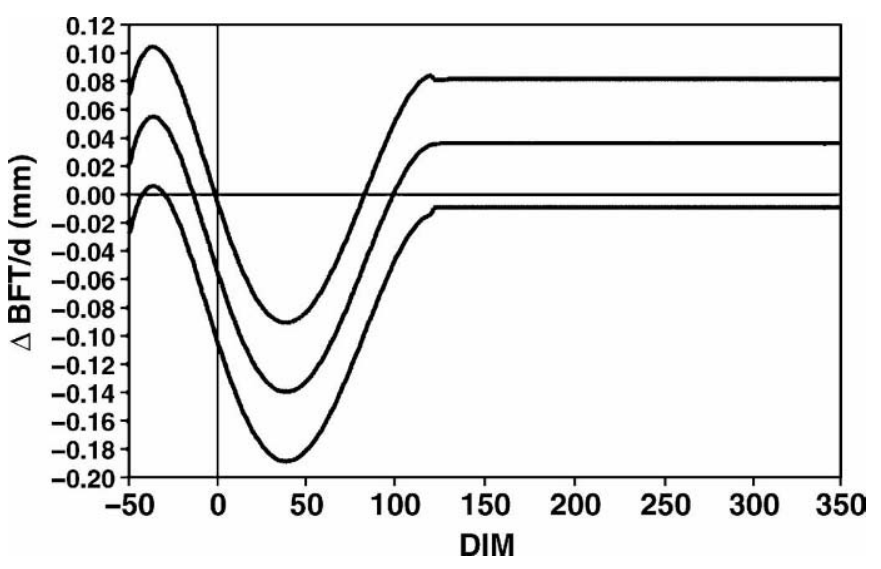

Figure 7. Reference curve for the daily change in backfat thickness ( $\triangle \mathrm{BFT} / \mathrm{d}$ ) throughout lactation for crossbred German Black Pied cows ( $\triangle \mathrm{BFT} / \mathrm{d} \pm 0.5 \mathrm{SE}$ ) computed by polynomial regression. Descriptive statistics: $\mathrm{n}=5,525$, fat-corrected milk yield $=8,280 \pm 1,644 \mathrm{~kg}$, lactation number $=2.5 \pm 1.5$, and days open $=123.9 \pm 71.7$. Regression equation for -50 to 120 DIM: $\Delta$ BFT/DIM $=-5.8 \times 10^{-2}-3.1 \times 10^{-3}$ $\mathrm{DIM}+3.22 \times 10^{-5} \mathrm{DIM}^{2}+7.2 \times 10^{-7} \mathrm{DIM}^{3}-9.7 \times 10^{-9} \mathrm{DIM}^{4}+$ $3.05 \times 10^{-11} \mathrm{DIM}^{5}\left[\mathrm{n}=2,595 ; \mathrm{SE}=0.105 ; \mathrm{R}^{2}=0.182 ;\right.$ Schröder and Staufenbiel (2003)]. 
using the BCS system (Ferguson et al., 1994) can be determined and computed on an individual or herd basis. These data can be related to production variables to evaluate the effects of the negative energy balance.

Moreover, assessing BFT by ultrasound is easy to learn and can be performed quickly in the field. It only takes a few seconds to get an accurate value of actual BFT. Depending on the housing system, about 100 cows can be evaluated in 30 to 60 min (Schröder, 2000) or even faster if head gates are available.

Because BCS and BFT are comparable, ultrasound measurements also may be used to train herd personnel in BCS to increase its precision.

\section{REFERENCES}

Andrew, S. M., R. A. Erdman, and D. R. Waldo. 1995. Prediction of body composition of dairy cows at three physiological stages from deuterium oxide and urea dilution. J. Dairy Sci. 78:1083-1095.

Bartle, S. J., S. W. Kock, R. L. Preston, T. L. Wheeler, and G. W. Davis. 1987. Validation of urea dilution to estimate in vivo body composition in cattle. J. Anim. Sci. 64:1024-1030.

Bauman, D. E., and W. B. Currie. 1980. Partitioning of nutrients during pregnancy and lactation: A review of mechanisms involving homeostasis and homeorhesis. J. Dairy Sci. 63:1514-1529.

Berghorn, K. A., R. D. Allrich, and C. H. Noller. 1988. Energy balance and reproductive traits of postpartum dairy cattle. J. Dairy Sci. 71(Suppl.1):171.

Bines, J. A., and I. C. Hart. 1982. Metabolic limits to milk production, especially roles of growth hormone and insulin. J. Dairy Sci. 65:1375-1389.

Bird, P. R., P. C. Flinn, J. W. D. Cayley, and M. J. Watson. 1982. Body composition of live cattle and its prediction from fasted liveweight, tritiated water space and age. Aust. J. Agric. Res. 33:375-387.

Boisclair, Y., D. G. Grieve, J. B. Stone, O. B. Allen, and G. K. Macleod. 1986. Effect of prepartum energy, body condition, and sodium bicarbonate on production of cows in early lactation. J. Dairy Sci. 69:2636-2647.

Braun, R. K., G. A. Donovan, T. Q. Tran, J. K. Shearer, E. L. Bliss, D. W. Webb, D. K. Beede, and B. Harris. 1986. Body condition scoring dairy cows as a herd management tool. Compend. Contin. Educ. Pract. Vet. 8:F62-F67.

Brethour, J. R. 1992. The repeatability and accuracy of ultrasound in measuring backfat of cattle. J. Anim. Sci. 70:1039-1044.

Bruckmaier, R. M., L. Gregoretti, F. Jans, D. Faissler, and J. W. Blum. 1998. Longissimus dorsi muscle diameter, backfat thickness, body condition scores and skinfold values related to metabolic and endocrine traits in lactating dairy cows fed crystalline fat or free fatty acids. J. Vet. Med. Ser. A 45:397-410.

Buskirk, D. D., R. P. Lemenager, and L. A. Horstman. 1992. Estimation of net energy requirements (NEm and NE delta) of lactating beef cows. J. Anim. Sci. 70:3867-3876.

Butler, W. R., R. W. Everett, and C. E. Coppock. 1981. The relationships between energy balance, milk production and ovulation in postpartum Holstein cows. J. Anim. Sci. 53:742-748.

Cameron, R. E. B., P. B. Dyk, T. H. Herdt, J. B. Kaneene, R. Miller, H. F. Bucholtz, J. S. Liesman, M. J. Vandehaar, and R. S. Emery. 1988. Dry cow diet, management, and energy balance as risk factors for displaced abomasum in high producing dairy herds. J. Dairy Sci. 81:132-139.

Chaiyabutr, N., S. Komolvanich, S. Sawangkoon, S. Preuksagorn, and S. Chanpongsang. 1997. The regulation of body fluids and mammary circulation during late pregnancy and early lactation of crossbred Holstein cattle feeding on different types of roughage. J. Anim. Physiol. Anim. Nutr. 77:167-179.
Chaiyabutr, N., S. Preuksagorn, S. Komolvanich, and S. Chanpongsang. 2000. Comparative study on the regulation of body fluids and mammary circulation at different stages of lactation in crossbred Holstein cattle feeding on different types of roughage. J. Anim. Physiol. Anim. Nutr. 83:74-84.

Chelikani, P. K., J. D. Ambrose, and J. J. Kennelly. 2003. Effect of dietary energy and protein density on body composition, attainment of puberty, and ovarian follicular dynamics in dairy heifers. Theriogenology 60:707-725.

Cole, N. A. 1995. Influence of a three-day feed and water deprivation period on gut fill, tissue weights, and tissue composition in mature wethers. J. Anim. Sci. 73:2548-2557.

Coppock, C. E. 1985. Energy nutrition and metabolism of the lactating dairy cow. J. Dairy Sci. 68:3403-3410.

Dolezal, H. G., J. D. Tatum, and F. L. Williams, Jr. 1993. Effects of feeder cattle frame size, muscle thickness, and age class on days fed, weight, and carcass composition. J. Anim. Sci. 71:2975-2985.

Domecq, J. J., A. L. Skidmore, J. W. Lloyd, and J. B. Kaneene. 1995. Validation of body condition scores with ultrasound measurements of subcutaneous fat of dairy cows. J. Dairy Sci. 78:23082313.

Domecq, J. J., A. L. Skidmore, J. W. Lloyd, and J. B. Kaneene. 1997. Relationship between body condition scores and milk yield in a large dairy herd of high yielding Holstein cows. J. Dairy Sci. 80:101-112

Edmonson, A. J., I. J. Lean, L. D. Weaver, T. Farver, and G. Webster. 1989. A body condition scoring chart for Holstein cows. J. Dairy Sci. 72:68-78.

Elanco. 1996. Body condition scoring in dairy cattle. Elanco Animal Health Bull. AI 8478. Elanco Animal Health, Greenfield, IN.

Faust, M. A., B. T. McDaniel, O. W. Robison, and J. H. Britt. 1988. Environmental and yield effects on reproduction in primiparous Holsteins. J. Dairy Sci. 71:3092-3099.

Ferguson, J. D., D. T. Galligan, and N. Thomsen. 1994. Principal descriptors of body condition score in Holstein cows. J. Dairy Sci. 77:2695-2703.

Ferrell, C. L., and T. G. Jenkins. 1996. Relationships between body condition score and empty body weight, water, fat, protein, and energy percentages in mature beef cows of diverse breeds. J. Anim. Sci. 74(Suppl.1):245. (Abstr.)

Flatt, W. P., P. J. Van Soest, J. F. Sykes, and L. A. Moore. 1958. A description of the energy metabolism laboratory at the U.S. Department of Agriculture, Agricultural Research Center in Beltsville, Maryland. Proc. 1st Symp. Energy Metabolism, Copenhagen, Denmark. Eur. Assoc. Anim. Prod. Publ. 8:53-64.

Fox, D. G., M. E. Van Amburgh, and T. P. Tylutki. 1999. Predicting requirements for growth, maturity, and body reserves in dairy cattle. J. Dairy Sci. 82:1968-1977.

Friggens, N. C., K. L. Ingvartsen, and G. C. Emmans. 2004. Prediction of body lipid change in pregnancy and lactation. J. Dairy Sci. $87: 988-1000$

Fronk, T. J., L. H. Schultz, and A. R. Hardie. 1980. Effect of dry cow overconditioning on subsequent metabolic disorders and performance of dairy cows. J. Dairy Sci. 63:1080-1090.

Gallo, L., P. Carnier, M. Cassandro, R. Dal Zotto, and G. Bittante. 2001. Test-day genetic analysis of condition score and heart girth in Holstein Friesian cows. J. Dairy Sci. 84:2321-2326.

Gallo, L., P. Carnier, M. Cassandro, R. Mantovani, L. Bailoni, B. Contiero, and G. Bittante. 1996. Change in body condition score of Holstein cows as affected by parity and mature equivalent milk yield. J. Dairy Sci. 79:1009-1015.

Garnsworthy, P. C., and J. H. Topps. 1982. The effect of body condition of dairy cows at calving on their food intake and performance when given complete diets. Anim. Prod. 35:113-119.

Gearhart, M. A., C. R. Curtis, H. N. Erb, R. D. Smith, C. J. Sniffen, L. E. Chase, and M. D. Cooper. 1990. Relationship of changes in condition score to cow health in Holsteins. J. Dairy Sci. 73:3132-3140.

Greiner, S. P., G. H. Rouse, D. E. Wilson, L. V. Cundiff, and T. L. Wheeler. 2003. The relationship between ultrasound measurements and carcass fat thickness and longissimus muscle area in beef cattle. J. Anim. Sci. 81:676-682. 
Grummer, R. R. 1993. Etiology of lipid-related metabolic disorders in periparturient dairy cows. J. Dairy Sci. 76:3882-3896.

Grüner, C. 1957. Bestimmung des Körperwassergehaltes mit Hilfe von Alkohol. Klin. Wochenschr. 35:347-354.

Hady, P. J., J. J. Domecq, and J. B. Kaneene. 1994a. Frequency and precision of body condition scoring in dairy cattle. J. Dairy Sci. 77:1543-1547.

Hady, P. J., J. J. Domecq, and J. B. Kaneene. 1994b. A computer based body condition management system: Case example. Compend. Contin. Educ. Pract. Vet. 16:1383-1390.

Hamlin, K. E., R. D. Green, L. V. Cundiff, T. L. Wheeler, and M. E. Dikeman. 1995. Real-time ultrasonic measurement of fat thickness and longissimus muscle area: II. Relationship between realtime ultrasound measures and carcass retail yield. J. Anim. Sci. $73: 1725-1734$.

Hasler, M., U. Eigenmann, F. Janett, and R. Thun. 2004. Körperkondition und Häufigkeit von Ovarialzysten bei Braunviehkühen während der ersten 40 Laktationstage. Schweiz. Arch. Tierheilkd. 146:213-221.

Heinrichs, A. J., G. W. Rogers, and J. B. Cooper. 1992. Predicting body weight and wither height in Holstein heifers using body measurements. J. Dairy Sci. 75:3576-3581.

Herdt, T. H. 2000. Ruminant adaptation to negative energy balance. Vet. Clin. North Am. Food Anim. Pract. 16:215-230.

Herdt, T. H., J. B. Stevens, J. Linn, and V. Larson. 1981. Influence of ration composition and energy balance on blood $\beta$-hydroxybutyrate (ketone) and plasma glucose concentrations of dairy cows in early lactation. Am. J. Vet. Res. 42:1177-1180.

Heuer, C., W. M. Van Straalen, Y. H. Schukken, A. Dirkzwager, and J. P. T. M. Noordhuizen. 2000. Prediction of energy balance in a high yielding dairy herd in early lactation: Model development and precision. Livest. Prod. Sci. 65:91-105.

Heuer, C., W. M. Van Straalen, Y. H. Schukken, A. Dirkzwager, and J. P. T. M. Noordhuizen. 2001. Prediction of energy balance in high yielding dairy cows with test-day information. J. Dairy Sci. $84: 471-481$.

Heuwieser, W., and R. Mansfeld. 1992. Beurteilung der Körperkondition bei Milchkühen. Teil 2. Milchpraxis 30:10-14.

Hix, E. L., G. K. L. Underbjerg, and J. S. Hughes. 1959. The body fluids of ruminants and their simultaneous determination. Am. J. Vet. Res. 20:184-191.

Hoffman, P. C., N. M. Brehm, S. G. Price, and A. Prill-Adams. 1996. Effect of accelerated postpubertal growth and early calving on lactation performance of primiparous Holstein heifers. J. Dairy Sci. 79:2024-2031.

Holter, J. B., M. J. Slotnick, H. H. Hayes, C. K. Bozak, W. E. Urban, Jr., and M. L. McGilliard. 1990. Effect of prepartum dietary energy on condition score, postpartum energy, nitrogen partitions, and lactation production responses. J. Dairy Sci. 73:3502-3511.

Houghton, P. L., R. P. Lemenager, G. E. Moss, and K. S. Hendrix. 1990. Prediction of postpartum beef cow body composition using weight to height ratio and visual body condition score. J. Anim. Sci. 68:1428-1437.

Houghton, P. L., and L. M. Turlington. 1992. Application of ultrasound for feeding and finishing animals: A review. J. Anim. Sci. 70:930-941.

Klawuhn, D. 1992. Vergleich der Rückenfettdicke mit dem über die Gesamtkörperwasserbestimmung ermittelten Körperfettgehalt bei Rindern. Vet. Diss., Humboldt-Univ. Berlin.

Klawuhn, D., and R. Staufenbiel. 1997. Aussagekraft der Rückenfettdicke zum Körperfettgehalt beim Rind. Tierarztl. Prax. 25:133-138.

Kock, S. W., and R. L. Preston. 1979. Estimation of bovine carcass composition by the urea dilution technique. J. Dairy Sci. 48:319-327.

Komaragiri, M. V. S., D. P. Casper, and R. A. Erdman. 1998. Factors affecting body tissue mobilization in early lactation dairy cows. 1. Effect of dietary fat on mobilization of body fat and protein. J. Dairy Sci. 81:169-175.

Komaragiri, M. V. S., and R. A. Erdman. 1997. Factors affecting body tissue mobilization in early lactation dairy cows. 1. Effect of dietary protein on mobilization of body fat and protein. J. Dairy Sci. 80:929-937.

Kunz, P. L., J. W. Blum, I. C. Hart, H. Bickel, and J. Landis. 1985. Effects of different energy intakes before and after calving on food intake, performance and blood hormones and metabolites in dairy cows. Anim. Prod. 40:219-231.

Laben, R. L., R. Shanks, P. J. Berger, and A. E. Freeman. 1982. Factors affecting milk yield and reproductive performance. J. Dairy Sci. 65:1004-1015.

Lalman, D. L., D. H. Keisler, J. E. Williams, E. J. Scholljegerdes, and D. M. Mallett. 1997. Influence of postpartum weight and body condition change on duration of anestrus by undernourished suckled beef heifers. J. Anim. Sci. 75:2003-2008.

Lassen, J., M. Hansen, M. K. Sørensen, G. P. Aamand, L. G. Christensen, and P. Madsen. 2003. Genetic analysis of body condition score in first-parity Danish Holstein cows. J. Dairy Sci. 86:4123-4128.

LeBlanc, S. J., K. E. Leslie, and T. F. Duffield. 2005. Metabolic predictors of displaced abomasum in dairy cattle. J. Dairy Sci. 88:159-170.

López-Gatius, F., J. Yániz, and D. Madriles-Helm. 2003. Effects of body condition score and score change on the reproductive performance of dairy cows: A meta-analysis. Theriogenology 59:801812.

Löschner, U., and R. Staufenbiel. 1996. Schätzung der Rückenfettdicke als Methode der Körperkonditionsbeurteilung bei Milchrindern. Prakt. Tierarzt 77:816-824.

Lucy, M. C., C. R. Staples, F. M. Michel, and W. W. Thatcher. 1991. Energy balance and size and number of ovarian follicles detected by ultrasonography in early postpartum dairy cows. J. Dairy Sci. 74:473-482.

Lukasi, H. C., W. A. Siders, E. J. Nielsen, and C. B. Hall. 1994. Total body water in pregnancy: Assessment by using bioelectrical impedance. Am. J. Clin. Nutr. 59:578-585.

Marlowe, T. J., R. J. Freund, and J. B. Graham. 1962. Influence of age, breed, flesh condition, nursing, and season on weight and grade of beef cattle. J. Anim. Sci. 21:346-354.

Martin, R. A., and F. R. Ehle. 1986. Body composition of lactating and dry Holstein cows estimated by deuterium dilution. J. Dairy Sci. 69:88-98.

Moe, P. W., W. P. Flatt, and H. F. Tyrrell. 1972. Net energy value of feeds for lactation. J. Dairy Sci. 55:945-958.

Moe, P. W., H. F. Tyrrell, and W. P. Flatt. 1971. Energetics of body tissue mobilization. J. Dairy Sci. 54:548-553.

Morrow, D. A. 1976. Fat cow syndrome. J. Dairy Sci. 59:1625-1629.

Morrow, D. A., D. Hillman, and A. W. Dade. 1979. Clinical investigation of a dairy herd with the fat cow syndrome. J. Am. Vet. Med. Assoc. 174:161-167.

Mösenfechtel, S., U. J. Eigenmann, M. Wanner, and P. Rüsch. 2000. Rückenfettdicke und Fruchtbarkeit bei Braunviehkühen. Schweiz. Arch. Tierheilkd. 142:679-689.

National Research Council. 1984. Nutrient Requirements of Beef Cattle. 6th rev. ed. Natl. Acad. Press, Washington, DC.

Nebel, R. L., and M. L. McGilliard. 1993. Interactions of high milk yield and reproductive performance in dairy cows. J. Dairy Sci. 76:3257-3268.

Otto, K. L., J. D. Ferguson, D. G. Fox, and C. J. Sniffen. 1991. Relationship between body condition score and composition of ninth to eleventh rib tissue in Holstein dairy cows. J. Dairy Sci. $74: 852-859$.

Panaretto, B. A., and A. R. Till. 1963. Body composition in vivo. II. The composition of mature goats and its relationship to the antipyrine, tritiated water, and $\mathrm{N}$-acetyl-4-aminoantipyrine spaces. Aust. J. Agric. Res. 14:926-943.

Parker, R. 1989: Using body condition scoring in dairy herd management. Ontario Ministry of Agriculture and Food. Factsheet 94053. ISSN 1198-712X.

Perkins, T. L., R. D. Green, and K. E. Hamlin. 1992. Evaluation of ultrasonic estimates of carcass fat thickness and longissimus muscle area in beef cattle. J. Anim. Sci. 70:1002-1010. 
Pryce, J. E., M. P. Coffey, and G. Simm. 2001. The relationship between body condition score and reproductive performance. J. Dairy Sci. 84:1509-1515.

Reid, J. T., and J. Robb. 1971. Relationship of body composition to energy intake and energetic efficiency. J. Dairy Sci. 54:553-564.

Reid, J. T., G. H. Wellington, and H. O. Dunn. 1955. Some relationships among the major chemical components of the bovine body and their application to nutritional investigations. J. Dairy Sci. 38:1344-1359.

Reist, M., D. Erdin, D. von Euw, K. Tschuemperlin, H. Leuenberger, Y. Chilliard, H. M. Hammon, C. Morel, C. Philipona, Y. Zbinden, N. Kuenzi, and J. W. Blum. 2002. Estimation of energy balance at the individual and herd level using blood and milk traits in high-yielding dairy cows. J. Dairy Sci. 85:3314-3327.

Rieckhoff, T. 1992. Aussage der Gesamtkörperwasserbestimmung und der Rückenfettdickenmessung zum Körperfettgehalt der Milchkuh. Vet. Diss., Humboldt-Univ. Berlin, Germany.

Robinson, D. L., C. A. McDonald, K. Hammond, and J. W. Turner. 1992. Live animal measurement of carcass traits by ultrasound: Assessment and accuracy of sonographers. J. Anim. Sci. 70:1667-1676.

Roche, J. R., P. G. Dillon, C. R. Stockdale, L. H. Baumgard, and M. J. VanBaale. 2004. Relationships among international body condition scoring systems. J. Dairy Sci. 87:3076-3079.

Rukkwamsuk, T., M. J. H. Geelen, T. A. M. Kruip, and T. Wensing. 2000. Interrelation of fatty acid composition in adipose tissue, serum, and liver of dairy cows during the development of fatty liver postpartum. J. Dairy Sci. 83:52-59.

Rukkwamsuk, T., T. A. M. Kruip, and T. Wensing. 1999. Relationship between overfeeding and overconditioning in the dry period and the problems of high producing dairy cows during the postparturient period. Vet. Q. 21:71-77.

Schröder, U. 2000. Untersuchungen zur Konditionsbeurteilung mittels ultrasonografischer Messung der Rückenfettdicke als Grundlage zur Anwendung in der Bestandsbetreuung von Milchviehherden. Vet. Diss., Freie Univ. Berlin, Germany.

Schröder, U., and R. Staufenbiel. 2003. Konditionsbeurteilung per Ultraschall in der Herdenbetreuung. Teil3: Berechnung von Referenzwerten. Tierarztl. Prax. 31(G):300-305.

Shell, T. M., R. J. Early, J. R. Carpenter, D. L. Vincent, and B. A. Buckley. 1995. Prepartum nutrition and solar radiation in beef cattle: I. Relationships of body fluid compartments, packed cell volume, plasma urea nitrogen, and estrogens to prenatal development. J. Anim. Sci. 73:1289-1302.

Smith, T. R., and J. P. McNamara. 1990. Regulation of bovine adipose tissue metabolism during lactation. 6. Cellularity and hormonesensitive lipase activity as affected by genetic merit and energy intake. J. Dairy Sci. 73:772-783.

Soberman, R., B. B. Brodie, B. B. Levy, J. Axelrod, V. Hollander, and J. M. Steele. 1949. The use of antipyrine in the measurement of total body water in man. J. Biol. Chem. 179:31-42.

Soderholm, C. G., D. W. Otterby, F. R. Ehle, J. G. Linn, W. P. Hanson, and R. J. Annexstad. 1986. Effects of different doses of recombinant bovine somatotropin (rbSTH) on milk production, body composition, and condition score in lactating cows. J. Dairy Sci. 69(Suppl.1):152. (Abstr.)

Spalding, R. W., R. W. Everett, and R. H. Foote. 1975. Fertility in New York artificially inseminated Holstein herds in dairy herd improvement. J. Dairy Sci. 58:718-723.

Spelbring, M. C., T. G. Martin, and K. J. Drewry. 1977. Maternal productivity of crossbred Angus $\times$ Milking Shorthorn cows. I. Cow and calf weights and scores. J. Anim. Sci. 45:969-975.

Staples, C. R., W. W. Thatcher, and J. H. Clark. 1990. Relationship between ovarian activity and energy status during the early postpartum period of high producing dairy cows. J. Dairy Sci. 73:938-947.
Staufenbiel, R. 1985. Untersuchungen zum Verhalten der NADPabhängigen Dehydrogenasen des Fettgewebes, der Fettgewebsbestandteile sowie der Plasmakonzentrationen an Insulin und Glucose und zu ihrer Aussage über die Lipogenese des Rindes. Vet. Diss., Humboldt-Univ., Berlin, Germany.

Staufenbiel, R. 1992. Energie- und Fettstoffwechsel des Rindes. Untersuchungskonzept und Messung der Rückenfettdicke. Mh. Vet. Med. 47:467-474.

Staufenbiel, R. 1997. Konditionsbeurteilung von Milchkühen mit Hilfe der sonographischen Rückenfettdickenmessung. Prakt. Tierarzt, Coll. Vet. 27:87-92.

Staufenbiel, R., B. Staufenbiel, I. Lachmann, and H. Lukas. 1991. Fettstoffwechsel und Fruchtbarkeit der Milchkuh. Prakt. Tierarzt. Sonderheft Coll. Vet. XXII:18-25.

Staufenbiel, R., B. Staufenbiel, N. Rossow, and F. Wiedemann. 1993. Energie- und Fettstoffwechsel des Rindes - Vergleich der Aussage der Rückenfettdicke mit anderen Untersuchungsgrößen. Mh. Vet. Med. 48:167-174.

Stevenson, J. S., and J. H. Britt. 1979. Relationships among luteinizing hormone, estradiol, progesterone, glucocorticoids, milk yield, body weight and postpartum ovarian activity in Holstein cows. J. Anim. Sci. 48:570-577.

Stevenson, J. S., S. K. Johnson, and G. A. Milliken. 2003. Incidence of postpartum anestrus in suckled beef cattle: treatments to induce estrus, ovulation, and conception. Prof. Anim. Sci. 19:124-134.

Tennant, C. J., J. C. Spitzer, W. C. Bridges, Jr., and J. H. Hampton. 2002. Weight necessary to change body condition scores in Angus cows. J. Anim. Sci. 80:2031-2035.

Van Winden, S. C. L., R. Jorritsma, K. E. Müller, and J. P. T. M. Noordhuizen. 2003. Feed intake, milk yield, and metabolic parameters prior to left displaced abomasum in dairy cows. J. Dairy Sci. 86:1465-1471.

Wagner, J. J., K. S. Lusby, J. W. Oltjen, J. Rakestraw, R. P. Wettemann, and L. E. Walters. 1988. Carcass composition in mature Hereford cows: Estimation and effect on daily metabolizable energy requirement during winter. J. Anim. Sci. 66:603-612.

Waltner, S. S., J. P. McNamara, and J. K. Hillers. 1993. Relationships of body condition score to milk production variables in high producing Holstein dairy cattle. J. Dairy Sci. 76:3410-3419.

Waltner, S. S., J. P. McNamara, J. K. Hillers, and D. L. Brown. 1994. Validation of indirect measures of body fat in lactating cows. J. Dairy Sci. 77:2570-2579.

Wappler, O. 1997. Vergleichende Untersuchungen zur Aussage des Harnstoffverteilungsraumes, der Lebendmasse und der Rückenfettdicke zum Körperfettgehalt der Milchkuh. Vet. Diss., Freie Univ. Berlin, Germany.

Washburn, S. P., S. L. White, J. T. Green, Jr., and G. A. Benson. 2002. Reproduction, mastitis, and body condition of seasonally calved Holstein and Jersey cows in confinement or pasture systems. J. Dairy Sci. 85:105-111.

Wellington, G. H., J. T. Reid, L. J. Bratzler, and J. I. Miller. 1956. Use of antipyrine in nutritional and meats studies with cattle. J. Anim. Sci. 15:76-85.

Wiedemann, F. 1984. Zur in vivo Bestimmung des Gesamtkörperwassers bei Rindern mit Pyrazolonderivaten. Vet. Dipl., HumboldtUniv. Berlin, Germany.

Wiedemann, F. 1989. Untersuchungen zur Rückenfettdicke und dem über das Gesamtkörperwasser bestimmten Körperfettgehalt bei weiblichen Jungrindern und Jungkühen. Vet. Diss., HumboldtUniv. Berlin, Germany.

Wildman, E. E., G. M. Jones, P. E. Wagner, R. L. Boman, J. R. Troutt, and T. N. Lesch. 1982. A dairy cow body condition scoring system and its relationship to selected production characteristics. J. Dairy Sci. 65:495-501.

Wittek, T., and M. Fürll. 2002. Untersuchungen zu Körperkondition und abdominalen Fettdepots in Beziehung zur Fettmobilisation bei an Labmagenverlagerung erkrankten Kühen. Tierarztl. Umsch. 57:302-309. 